\title{
Heptanoic Acid
}

National Cancer Institute

\section{Source}

National Cancer Institute. Heptanoic Acid. NCI Thesaurus. Code C61782.

An aliphatic carboxylic acid, also known as enanthic acid, used in the synthesis of esters

for products such as frag rances and artificial flavor preparations. 